\title{
Reconstructing the Past as a Means of Rationalizing the Present: A Study of Kazuo Ishiguro's The Remains of The Day (1989)
}

\author{
Mohamed Fathi Helaly Khalaf \\ College of Arts and Science, Prince Sattam Bin Abdulaziz University, Saudi Arabia \\ E-mail: drhelaly_2010@hotmail.com
}

Received: 12-12-2016

Published: 01-07-2017
Accepted: 20-02-2017

doi:10.7575/aiac.ijalel.v.6n.4p.173
Advance Access Published: April 2017

URL: http://dx.doi.org/10.7575/aiac.ijalel.v.6n.4p.173

\begin{abstract}
The postwar world period was riddled with rapid changes at the different levels. Many people felt they were not able to come to terms with such ongoing changes and had to find a way to coexist with the status-quo. Postmodernism looks upon man as a social being that should learn how to adapt himself to whatever situation by whatever means available. Ishiguro's novels are written in an expanded humanistic tradition. They are stories dealing with human relationship. They are narratives centering on the working of consciousness and the unconsciousness of the human mind. Ishiguro is concerned with reworking of the past from a late twentieth century perspective. The purpose of this study is to trace the postmodern aspects in The Remains of The Day through the life and character of Stevens and his relationships with the people that he has lived with. Stevens struggles to come to term with his present through telling stories and anecdotes of his past life. The novel depicts the role that memories can play in reconstructing the past events so that the present can be meaningful in some way from a postmodern standpoint. As a postwar British individual, the protagonist of the novel tries to practice suppression over his emotions at the personal level as well as the professional level to construct a new identity. Stevens appears torn between memories of the past and the representation of the present. He is suffering from an identity crisis and striving to create a meaningful present for himself. As a postmodern man, Stevens has to struggle at different levels. He is leading a life riddled with inconsistencies and contradictions. He can't feel at home with the surrounding world as he is always busy trying to achieve some perfection that is not attainable in a world riddled with conflicts and struggle.
\end{abstract}

Keywords: reconstruction, rationalize, past, present, postmodernism, inconsistency, contradiction, fragmentation, memory, professionalism, suppression, crisis

\section{Introduction}

We live in a world where everything is changing around us. Such changes exist not only in people's lifestyles but also in their way of thinking, behavior, psychic and the way they look upon the surrounding world with its ever changing events. These events always have their impact both on short terms as well as long ones. For people, to come to terms with this ever changing world with its ever-changing events, they have to find a way that might enable them to circumvent the consequences of such change; each according to the way he sees as convenient. In doing so, the individual conduct himself in a way that others might see as inadequate to them. As such, the modern man finds himself living a life of anxiety at a variety of levels. He finds himself in a dilemma either to accept the present world or to find a way to create a world of his own. That is to say the individual has to adopt certain strategies to co-exist with the modern world and its changes.

The modern man is suffering from an identity crisis. This crisis manifests itself in his feeling of estrangement and alienation. He develops a sense of uneasiness that is reflected in his sense of uncertainty. He also suffers from a sense of self-fragmentation that compels him to live a distracted life of some kind. He suffers from a problem with identity as he finds himself in a dilemma either to identify himself with the present or to look at the past to reconstruct it in a way that enables him to find meaning in the present. That is to look at the past to find something to rationalize his existence in the present. Sometimes people find in their past memories what might give them some energy to coexist with the present. Furthermore, the modern man finds in hiding his real feelings toward the world surrounding him a new means to create a world of his own. A world that is governed by a set of values and norms that constitute the moral code of his own.

\section{Kazuo Ishiguro as a Postmodern Novelist}

Kazuo Ishiguro is a Japanese born British writer who was born in 1954 in Nagasaki. He moved with his family to England for his father's job when he was five. In England he spent his childhood. There, he studied English and philosophy at the University of Kent, Canterbury. Later, he got a Master's Degree in creative writing at the University of East Angelia. In London he worked as a social worker and there he published his first novel A Pale View of Hills in 
1982. He won the prize of the Social Society of Literature. Ishiguro wrote a number of great novels dealing with contemporary themes. He wrote An Artist of The Floating World in 1986, The Unconsoled in 1995, When We Were Orphans in 2000, Never Let Me Go in 2005, The Buried Giant 2015 and his The Remains of The Day which was nominated to the Booker Prize in 1989.

Ishiguro's novels are written in an expanded humanistic tradition. They are stories dealing with human relationship. They are narratives centering on the working of consciousness and the unconsciousness of the human mind. Ishiguro is concerned with reworking the past from a late twentieth century perspective. As a social worker, he sees that memories can play an instrumental role in adapting to the present with its circumstances and needs and that separating history from the present can result in crises mainly with identity and existence. As Diane Thomas opines:

For Ishiguro, the past in memories is part of the present and the future. The ruptures of history are the crises and traumas of change and the loses and fragmentation caused by post wars. Memories provide the context in which Ishiguro's central characters try to negotiate meaning and identity in their ordinary lives. (Thomas 2012, 12)

Ishiguro portrays characters as having connection with their past. Such characters have made choices in the past and have to face their consequences in the present. As Sutcliffe points out "Ishiguro's narrators have suffered a deep rupture in their lives, are often fighting a long standing battle to relate their past to the present with which it does not seem to fit." (Sutcliffe 2000, 13)

Living in a post-war world, Ishiguro's characters find themselves in a dilemma. This dilemma manifests itself in the inconsistencies between the past and the present. This creates a state of uncertainty about the kind of lives they are living. That is to say they are suffering from an identity crisis. In other words, Ishiguro's characters experience a conflict between what they do, narrate or seem to be and the reality of the interpretation of their actions or narrations. Their memories of the past are distorted. Such memories are rendered in a way that contradicts their present being or identity. Consequently, they are distracted between the past and the present and this represents the core of the identity crisis they are suffering from. As Cynthia Wong remarks:

Ishiguro's characters are revealed to be carrying complicated states of being ... Their narratives are riddled with inconsistencies or awkward insistence; this may be the result of a memory that is also struggling to bring to the surface painful events and to find a language that can adequately express the unending trauma of their affiliation. (Wong 2005, 24)

\section{The Remains of the Day from a Postmodern Standpoint}

The Remains of The Day is the novel written by Ishiguro in 1989. It was awarded the Man Booker Prize for fiction in 1989. It is a story told in retrospect in which Stevens, a butler, recalls his past life while the action progresses through the present. The novel deals with Stevens' profession and his relationship with others mainly with his former colleague Miss Kenton, his father and his master lord Darlington. The Remains of The Day was set in 1956 in a postwar English society that was torn between an imperial past and a new globalized world. During this period the British empire was undergoing drastic changes at the international level.

The Remains of The Day is a novel in which some aspects of postmodernism can be traced in Stevens' life and relationships with the people that he has lived with. Stevens struggles to come to term with his present through telling stories and anecdotes of his past life. Pinpointing the crisis that the modern man experiences as a result of his loss of a sense of identity, Daniela Carpi states:

The crisis concerning the idea of the subject is one of the main elements that typify our contemporary postmodern era. If some of the key words to understand the postmodern situations are in fact the terms "uncertainty"; homelessness and fragmentation. We may assert that the concept of subjectivity is also part of a more general transformation.... The subject finds itself wavering between a plunge towards the past in search of a lost sense of roots, and a drive to some kind of future freedom from all frets and limitations. (Carpi 2012, 2)

The Remains of The Day portrays the suppressed emotions of the postwar people represented in the character of Stevens. The novel depicts the role that memories can play in reconstructing the past events so that the present can be meaningful in some way. As a postwar British individual, the protagonist of the novel tries to practice somekind of suppression over his emotions at the personal level as well as the professional level to construct a new identity. Stevens appears torn between memories of the past and the representation of the present. He is suffering from an identity crisis and striving to create a meaningful present for himself. Here, he attempts to adapt to the new world to harmonies both past and present. As Sebastian Groes points out “The power of Ishiguro's fiction lies in its ability to make us care about the world, about other people, about ourselves. The carefully crafted narrative invites us to invest our time and emotion in his fictional worlds and characters." (Groes 2011, 26)

The Remains of The Day is one novel that urges the reader to look into the consequences of the two world wars and the devastating impact they had created in the soul and mind of the modern man. The protagonist expresses fragmentation of the self as he lives distracted between his memories of the past and present in which he shows how he is sometimes compelled to tell lies and at some other times he has to repress his feeling in a way to protect himself from painful experience and to maintain a new self that is a new identity. Memories are of great importance to recall certain events that are consistent with how he would have wanted to live. 


\section{Stevens as a Postmodern Character}

The Remains of The Day tells the story of Stevens, the main character, a butler who has been working as a chief butler for Lord Darlington; an English aristocrat during the first half of the $20^{\text {th }}$ century. Stevens dedicates his entire life to the service of his employer denying himself the possibility of expressing his personal feelings and emotions or even free personal opinion. Now, the Darlington Hall, which is a great manor house, is owned by the American Mr. Farraday. He could observe that Stevens is leading a life devoid of any recreational acts. Mr. Farraday encourages Stevens to go on a picnic in the Western Countryside. At the professional level, Stevens decides to take advantages of his trip to pay a visit to his former colleague at Darlington Hall Miss Kenton. Farraday says to Stevens "It is wrong that a man can't get to see around his own country. Take my advice; get out of the house for a few days." (Ishiguro 5)

As a man living in the postwar era, Stevens has to struggle at different levels. He is leading a life riddled with inconsistencies and contradictions. He can't feel at home with the surrounding world as he is always busy trying to achieve some perfection that is not attainable in a world riddled with conflicts and struggle. It is a world where people feel that they no longer have that sense of integrated identity. Stevens tends to ignore or rather forget his own feelings and, moreover, he tends to forget some memories of the past as a means to co-exist with the present. He is torn between the past and the present. As Cynthia Wong points out "Stevens is unable to account equivocation without revealing the nature of his own wasted existence." (Wong 2005, 7)

As the story progresses Stevens meets many people and recalls a lot of his past memories in Darlington Hall. In fact, Stevens does not recall all his memories. He ignores certain memories especially those connected with feelings and emotions. He does so because recalling such memories is painful for him. His regret over certain memories is overwhelming. As Eva Szederkenyi remarks "Stevens is blocked by trauma and cannot verbalize or express his emotions in other ways and those elements with the most painful memories are told in retrospect following the logic latent memories making their way to the surface." (Szederkenyi 2014, 10)

In narrating his past, Stevens suppresses his feeling in a way to protect himself and to maintain his own sense of dignity. Sometimes what he narrates is unreliable as he sees, sometimes, in telling lies a means to avoid pain and he tries to be proud of his achievement as a butler. Stevens' life is also riddled with misunderstanding and incoherence as a result of his past life as a dedicated butler at Darlington Hall. Stevens lives a life of distraction devoid of harmony. Teruko points out Stevens is caught between the necessity of confession and the anxiety of inhabitation as he remembers his past experiences." (Teruko 2010, 366)

As a modern man, Stevens' dilemma also lies in a lot of inconsistencies and contradictions that he has in his character between the life he has lived and the life he is leading at the present time. Such inconsistencies and contradictions are especially connected with his profession. Stevens uses these contradictions and inconsistencies to conceal certain feelings regarding his past life. In this regard Zuzana Foniokova remarks "Stevens tries to justify his actions by presenting it as the only possible way of dealing with the situation and uses his devotion to the ideal of great butler. His philosophy of dignity serves as a means to rationalize his suppression of emotions." (Foniokova 2006, 94)

\section{Stevens' Concept of Professionalism}

Having lived a life riddled with distraction and disharmony, Stevens comes to justify his past life in a way that enables him to make of the present something meaningful in someway. Now, in the form of memories, he recalls how he has conducted himself and how it has been a life characterized by a set of personal values that he sees as the principles of his professional life. The whole of Stevens' life amounts to his professional as a butler. He philosophizes that his aim in life is to achieve perfection. He states “

Great butlers will not be shaken by external events, however surprising, alarming or vexed. They wear their professionalism as a decent gentleman will wear his suit; he will not let ruffians or circumstances tear it off him in the public gaze. It is, as I say, a matter of dignity.” (Ishiguro, 23)

As the chief butler at Darlington Hall, Stevens is so much concerned with the orderly running of the house that he often sacrifices its welfare over his own private life. He is profoundly obsessed with the affairs of the house. He says "I spend many hours working on the staff plan and at last as many hours again thinking about it as I went about other duties." (Ishiguro 8) Stevens dedicates his entire life to the service of his employer. He spends his life seeking to serve his master with blind obedience, submission and even repression of his personal feelings and emotions.

Generally, dignity can be defined as having the quality or developing a state of being that is appreciated as worthy, honored and esteemed in any social context. However, to Stevens, dignity has a different meaning with different connotations. He looks upon dignity only from his own professional standpoint. For him "dignity" has a meaning that is completely connected with profession. As the story tells, he sees dignity as repressing feeling and this he takes as his ideal goal in life. As Penner underscores "Stevens' life is a monument to dignity for his dignity is a defining characteristic of the great butler that he struggle to explain." (Penner 1999, 28)

As a butler, Stevens does not allow himself to express opinion or show curiosity or emotion in carrying out his duties. He prevents himself from accepting anything that might deter him from fulfilling his duties. As Rocio Davis remarks "Stevens is so out of touch with his own feelings that he does not recognize love when it comes. He is obsessed with personal perfection." (Davis 2007, 5) Stevens develops emotional restraint that it has become the center of his life and 
his definition of dignity. Stevens sees s self-contained dignity as inevitably crucial to his sense of professionalism. As Saranne Weller puts it:

Stevens' self-contained "dignity" as the prime principle of professionalism and enacting this dignity comes at the expense of his personal relationships and his own undisclosed values. His confidence in this rightness of his professional beliefs demand that he comprises both his professional land his ability to act on his professional knowledge. (Weller 2007, 775)

Again, Stevens' concept of dignity entails repressing any wish, emotions or even opinion that do not conform to the principles of his profession. In his view, a butler should remain a butler regardless of any circumstances. Professional dignity never revealing his true feelings toward others. As Dalrympe points out:

Stevens' misguided concept of dignity that he constituted on professional ground does not allow him to have the possibility of intimacy with others. Stevens insists on repressing his emotion and does not give any space for them in the name of professional duty. (Dalrympe $2011,10)$

Stevens rationalizes his philosophy of dignity on his own way. He thinks that memories of the past enables him to construct a new identity and that such memories are the means for finding solace in a world that is not consolable. Lalrinfeli points out "the concept of identity which is constructed in narratives is dependent on the function of memories and the kind of access it gives to the past. In essence, memory is the fundamental force behind identity formation and self-understanding." (Lalrinfeli 2012,9)

\section{Stevens and Lord Darlington}

As the story begins, Stevens has been working for thirty four years at Darlington Hall. He has worked for thirty years for Lord Darlington and for four years for the American Mr. Farraday. Throughout these thirty four years, Stevens has been a very dedicated butler devoting his life to the service of his employers. To Lord Darlington, he has shown all commitments and full responsibility. Stevens' service to him has been marked by blind obedience and perfection. On the one hand, Lord Darlington sees Stevens as a perfect butler in whom he has great trust and reliance. On the other hand, Stevens develops a great sense of professionalism and perfection accompanied by a great sense of satisfaction and self-complacence.

On his trip to the West Country, Stevens recollects his memories at Darlington Hall with Lord Darlington. In recollecting such memories, Stevens appears as dutiful, serious-minded and anxious to do only what he sees as right in the name of professionalism. He is caught up in his own dream of serving a gentleman of international fame. As the story progresses, Stevens goes on recalling situations in which he appears so proud of working for Lord Darlington. Furthermore, there is some mutual understanding between him and his employer that maintains some great intimacy between the two. Such understanding is achieved mainly as a result of his high sense of professionalism. Stevens develops a firm belief and a firm impression about the goodness of his master. He develops a set of values of his own in light of the different circumstances that have shaped him as a butler. He could create a world of his own in which he creates words like "dignity" and professionalism to achieve perfection. As Iverson points out "Stevens has become a prisoner of his own values, of his time and of his perception. He is trapped inside his own illusion and imaged of "the great butler. The way he has chosen to live doesn't give him any alternation." (Iversen 2014, 47)

Stevens always thinks of Lord Darlington highly considering him as the best employer. He spends his life endeavoring to serve him perfectly. There is little else in his life to identify himself with other than his role as a perfect butler. He claims:

If a butler is to be of any wrath to anything or anybody in his life, there must surely come a time when he ceases his search, a time when he must say to himself. This employer embodies all that to find noble and admirable. I will hereafter devote myself to serving him. (Ishiguro, 133)

The postwar period has witnessed a lot of turmoil on the international level especially in the European region. The international political map has undergone some changes especially after the deterioration of the power of the British Empire. As a novel set after World War I, The Remains of The Day depicts the overwhelming impact of the war on the European nations. Lord Darlington is a man of high profile and international fame especially among the European countries. He is in the habit of entertaining people of high statures from different parts of Europe. He also holds international conferences in an attempt to settle the differences among the conflicting parties. Lord Darlington is generally known as having some sympathy toward Germany. He is greatly influenced by the conditions of the German people especially he close friend Mr. Bremann. Mr. Bremann has committed suicide because of the bad economic condition in which he has lived. Also, some visitors of Darlington Hall have been anti-sematic and members at the British Fascist Union. Such visitors have been of great influence on Lord Darlington. To please his guests, Lord Darlington develops sympathy with the Nazi.

Amongst the staff working under Stevens at the Darlington Hall are two Jewish maids. Out of his sympathy with the German and out of his desire to please his guests including the English, Lord Darlington decides to fire the two Jewish 
maids. One day, Stevens is summoned by Lord Darlington and the latter asks the former to dismiss the two Jewish maids.

Lord Darlington: I've doing a great deal of thinking Stevens. We cannot have Jews on the staff here at Darlington Hall.

Stevens: Sir. I believe two of the present staff members fall into that category.

Lord Darlington: Of course, you'll have to let them go. (Ishiguro,97)

Here, Stevens appears as an obedient and committed butler to his mater though -inwardly- does not welcome the dismissal of the Jewish maids stating that his "every instinct opposed the idea of their dismissal. (Ishiguro 98) Stevens obeys the command without questioning it. He says to Miss Kenton "His lordship has made his decision and there is nothing for you and me to debate over." (Ishiguro 97)

Stevens does not like the dismissal of the Jewish maids, yet he could not express his opinion freely and, as usual, he suppresses it. Moreover, he scolds Miss Kenton upon her decision against this act asking her to conduct yourself in a manner befitting your position. He goes to justify his compliance with his masterls command by convincing himself that as a butler he is not eligible to make judgement on such crucial issues labelling her as "foibles and sentiment that should be suppressed in compliance with the employer's wish." (Ishiguro, 99) In this regard Zuzana Foniokova points out:

Stevens suppresses his personality and never reveals his true feelings. This entails repression of all wishes, emotion and even opinion that don't conform to the profession. This repression is what he call "dignity" ... Stevens pursuit of dignity services him as an aid for repressing himself. (Foniokova. 2006, 90)

As the story progresses, Stevens is stirred to talk about his attachment to Lord Darlington. He states:

Lord Darlington wasn't a bad man. He was not a bad man at all and at least he had the privilege of being able to say at the end of his life ... he chose a certain path in life, it proved to be a misguided one ... I trusted in his lordship's wisdom. All these years I served him. I trusted that I was doing something worthwhile. (Ishiguro, 163)

As a man living in the postwar period, Stevens' character also undergoes some anxiety. This anxiety manifests itself in some inconsistencies and contradictions in his life especially his profession. In fact, Stevens uses such inconsistencies to mask certain feelings regarding his past. In his view, a butler should remain a butler under any circumstances and this requires considerable restraint. Sometimes he has to suppress his personality and never reveals his true feeling. This also entails all wishes, emotions and even opinions that do not conform to the profession. This is what Stevens calls "Dignity".

Early in the novel, Stevens appears as very proud of working for a man of international fame like Lord Darlington. Whenever he is asked about his mater, Stevens speaks highly of him. However, toward the end of the novel and after the demise of Lord Darlington, Stevens develops some feeling of shame to acknowledge his previous attachment to him as the former has been known for siding with Nazi and this is not appreciated by the British society. When asked by his American visitor to the Darlington Hall "but tell me Stevens what was this Lord Darlington like? Presumably you must have worked for him." Stevens replies "I didn't, madam, no." (Ishiguro 84) Here, Stevens' denial of working for Lord Darlington can be seen as Scherzinger puts it "Striking symptom of Stevens general anxiety about his identity that gnaws his composure and is only partly tamed by his typical responses of rationalization and deferment." (Scherzinger. 2004, 12)

Of course, what Stevens is stating about Lord Darlington now contradicts his early statement about him. Earlier, he praises his master saying "Whatever may be said about his lordship these days, and the great majority of it is, as I say, utter nonsense. I can declare that he was a truly good man at heart, a gentleman through and through, and one I am today proud to have given my best." (Ishiguro, 86)Here, on the whole, in his attitude toward Lord Darlington, Stevens appears as having a conflict. This conflict manifests itself in his contradictory attitude toward his employer. It is an attitude that oscillates between recognition and denial, pride and humanity. Again, such inconsistencies and contradictions in attitudes as well as ambivalence in feelings are characteristics of the identity crisis that Stevens has been undergoing and his endeavor to construct a new being

\section{Stevens and his Father}

Stevens' father was a great butler. He has worked for Mr. John Silvers, a great British industrialist. Stevens' father is a professional butler who has developed a concept of professionalism based on blind obedience and commitments to hid duties toward his employer. Previously, Stevens has worked as a footman under the supervision of his father. From his father, Stevens has learned the principles of the profession. The father has told Stevens some anecdotes to explain the meaning of being a professional butler. In his relationship with his father, Stevens appears not a grateful son. He does not have those natural feelings that a son develops towards his father. Stevens-father's relationship lacks that natural bond that exists between a parent and his children. 
Stevens identifies with his father as a butler rather than a father. He sees his father as a dignified butler. He rarely visits his father at his room. He deals with his father as a member of the staff at the Darlington Hall. Stevens cannot notice his father's deteriorating health which is observed by Miss Kenton. Stevens addresses his father in the third person as if he were an abstract entity. Stevens' father's health deteriorates as he is getting older. Now, he is working under the supervision of his son. It happens that the father is carrying a tray to serve teat to Lord Darlington and one of his guests. The tray falls down and Stevens is asked by Lord Darlington to relieve his father of service.

Stevens: I have come to relate something to you Father.

Father: Then relate it briefly and concisely. I haven't all morning to listen to you chatter.

Stevens: Come to the point then and be done with it. Some of us have work to be getting on with. (Ishiguro, 44)

Gradually, the father falls ill and Stevens appears oblivious about the situation. Commenting on his father's new status as a member of staff, Stevens said:

Father has become increasingly infirm .... His lordship is of the view as indeed I am myself, he represents an ever-present threat to the smooth running of this household ... It has felt that Father should no longer be asked to wait at table whether or not quest are present. (Ishiguro, 44)

In his relationship with his father, Stevens goes to suppress his emotions in the name of professionalism. He considers this suppression of feelings one feature of the professional dignity he assumes. Stevens and his father do not speak with each other than professional matters and the little communication takes place in an atmosphere of embarrassment. As Foniokova remarks "They have suppressed their emotions with the aim of becoming great butlers. They have lost their ability to pursue human conversation." (Foniokova 2006, 93) Of course, such lack of communication creates some sort of lack in understanding between the two. Ignoring his father's age, Stevens goes to treat him coldly leaving no space for intimacy or gratitude. "Stevens acts as superior to his father but not as a son. Furthermore, he defends his attitudes for being cruel to his father saying that he pursues dignity." (Teruko 2010,363)

Again, Stevens' relationship with his father is not an intimate one rather it is a formal one. Despite living in the same house, he rarely visits his father in his chamber justifying this by saying "I had rarely had reason to enter my father's room ... and I was newly struck by the smallness and starkness of it" (Ishiguro 43) Furthermore, Stevens formal conduct with his father can be clearly seen in Stevens' reference to his father in recollecting his memories at the Darlington Hall using the capital "F". Here, Stevens refers to his father as a formal title but not as an ordinary father. Thus, Stevens' formal conduct with his father is looked upon within his concept of professional "dignity" As Susie G. Brien remarks "Stevens' attitude to his father is consistent with his reliance on an anachronistic social order to provide him with a sense of self-definition. His memories of his father's restraint and fortitude and is crucial to his sense of dignity." (O’Brien 1996, 806)

Stevens' father falls ill and Stevens appears oblivious about his father's illness as he is busy serving Lord Darlington and his guests. Miss Kenton calls Stevens to inform him about his father's deteriorating health conditions. Moreover, she goes to call a doctor from the French delegate while Stevens is busy arranging for the conference. Stevens' response is confined to "everything in hand downstairs? Yes, I dare say you can rest assured on that ... I am so glad you're feeling better now." (Ishiguro, 67) Stevens appears so busy with the banqueting hall. His reaction toward the illness of his father is not an adequate or acceptable one but he reasons this saying that he is in duty. When the father develops a stroke, Stevens is summoned as a result. He says "This is most distressing, I must now return downstairs." (Ishiguro, 72) Yet, in such distressing circumstances, Stevens continues his work and barely spares time to see his dying father justifying his situation by saying that he has continue doing his duty as his father would have wanted him to do.

Here, again Stevens fails to communicate with his father. Moreover, he goes to refer to him using the third person. Stevens is practicing a very high level of restraint over his reaction toward the situation. He tries his best not to show his real feelings to his employer or to the guests. One of the guests (Mr. Cardinal) asks him "Stevens are you all right? You look as though you're crying." (Ishiguro, 73) Stevens replies "I am very sorry, Sir. The strain of a hard day." (Ishiguro, 73) Stevens' father, eventually, dies and when he is informed about his death, Stevens replies saying "I see." and goes to resume his work again. Here, Stevens, reaction toward the situation as a whole starting from the father's illness to his death can be seen as normal when interpreted from a professional point of view as acceptable. He himself considers such commitments as part of his professional dignity. Really, it is a mistaken concept of dignity. Stevens tries to justify his action through presenting it as the only possible way of dealing with his father's illness and death on the ground of his concept of being a good butler. As Foniokova points out "Stevens avoids dealing with emotionally difficult situation of his father's illness under the pretext of urgent professional duties and this escape from unpleasant feelings into the safety of his job." (Foniokova 2006, 94)

\section{Stevens and Miss Kenton}

Miss Kenton is the housekeeper who has worked with Stevens at the Darlington Hall during the days of Lord Darlington. She has joined the staff at Darlington Hall at the same time Stevens' father has joined. Miss Kenton appears as a perfect housekeeper. Stevens describes her as a dedicated professional housekeeper who shows full responsibility and commitment toward her profession. Unlike Stevens, Miss Kenton appears

as audacious to speak her mind freely. 
Though she is professionally perfect in the same way Stevens is, she develops some sort of inward affection toward Stevens. Miss Kenton has left Darlington Hall for some years for the purpose of getting married to Mr. Benn.

Just before Mr. Farraday's suggestion that Steven go on a trip across the English countryside, Stevens has received a letter from Mrs. Benn, former Miss Kenton, informing him about her present condition. She currently lives away from Mr. Benn's house with a friend of her. Upon receiving her letter, Stevens reads it to find that she is showing nostalgia to Darlington Hall. He starts to think seriously of going in the expedition suggested by his new employer Mr. Farraday. Stevens goes to justify his acceptance of the offer made by his employer from a professional point of view. Apparently, there is some shortage in staff and he hopes that Miss Kenton will join the Darlington Hall. He admits that she is a perfect housekeeper who can fully care for Darlington Hall. He says "This very shortage that had been at the heart of all my recent trouble. And the more I consider it, the more obvious it became that Miss Kenton, with her great affection for this house." (Ishiguro, 8)

Primarily, Stevens believes that a butler should not have any romantic relationship with any housekeeper or house maid. He believes so because such relationships will not allow them to serve their employer in a perfect way. Stevens' relationship with Miss Kenton can be felt from the beginning. His reaction toward the letter reflects his hidden feelings toward her. However, he wants to practice some sort of control over these feelings through finding an acceptable channel from the professional point of view. The letter gives him some hope for a reunion. From the letter he understands that she is in trouble. Immediately, he develops a desire to see Miss Kenton and wants to take advantage of his trip to visit her. As Teruko points out "What Stevens sees in Miss Kenton's letter is the reflection of his inner world. The epitome stretching out before the rest of life is not Miss Kenton's feeling, but his own. He seems to have imagined her being unhappy because it makes him feel better." (Teruko 2010, 366)

Stevens wants to convince himself as well as the reader that he is not doing anything that does not fit in with the demand of his job. Miss Kenton's letter acts as a driving force for Stevens to decide to go on this journey stating that the trip "couldn't be put to good professional use... Why should I hide it. ... I can see no genuine reason why I should not undertake this trp." (Ishiguro, 15) Still he tries to be committed to his professional dignity which denies him favoring any personal relationship over professionalism. Foniokova remarks "In his relationship with Miss Kenton, Stevens prevented his professional relationship from deviating from the proper basis and therefore ruled out the possibility of romance between them." (Foniokova 2006, 95)

As a matter of fact, Miss Kenton's letter does not include any hint at her desire to return to the Darlington Hall but Stevens constitutes such an impression out of his wishful thinking. In his phantasy Stevens figures out that she has briefly left her husband and that she is in trouble seeking his help. In his first response, Stevens projects his own attributively into her. He states:

It is of course tragic that her marriage in now ending in failure. No doubt she is pondering with regret decisions that have left her, deep in middle age, so alone and desolate .... Of course, Miss Kenton cannot hope ..... to retrieve those lost years .... I cannot say why her seeing out her working years there should not offer a very genuine consolation to a life that has come to be dominated by a sense of waste. (Ishiguro, 32)

As Stevens embarks on his trip, he rereads Miss Kenton's letter for the third time. One day before his encounter with her, Stevens becomes emotionally disengaged and retreats into denial of their expected meeting. He says "side from a few informal exchanges, it will be essentially a professional one." (Ishiguro 118) of course, Stevens rereading of the letter more than one time implies his own interest in Miss Kenton herself. However, he discovers that there is no concrete statement that indicates her desire to return to Darlington Hall. He admits that he has misunderstood her real intent. He states "But the fact is that the letters I have had from you over the years and in particular the last letter, have tended to suggest that you're ... rather unhappy. I simply wondered if you were being ill-treated in some way." (Ishiguro, 159)

At another level, Stevens insists on referring to his former colleague using her maiden name Miss Kenton and ignoring her new married name Mrs. Ben. Of course, such insistence on the part of Stevens gives him some hope of reunion and this can be seen as an introspection of his inner feelings towards her. Here, Stevens' conducts shows some sort of incoherence and inconsistency toward the only woman who once has, inwardly, developed some romantic feelings. In this regard Johansson points out "By calling her Miss Kenton, he wants to avoid the otherwise constant reminder of her marriage. He prefers to her using her maiden name.” (Johansson 2011, 7)

On his trip and upon his encounter with Miss Kenton, Stevens asks her if she is unhappy as a result of leaving her husband Mr. Ben, Miss Kenton's reaction to Stevens' query is very impressive. Tears start to flow from her eyes telling him that her life would have been better, had she got married to him. As the story tells, Stevens tells a stranger about his feelings at that time saying "at that moment, my heart was breaking." (Ishiguro, 161) Stevens starts to recall incidents and recollect5s memories between him and Miss Kenton. One day, while Stevens if off duty. Miss Kenton goes to his parlor carrying some flowers to brighten his gloomy room. Generally, flowers are a symbol of love and romantic feelings. Stevens' reaction to the flowers is one of rejection and disappreciation rather than thanks and acceptance. He tells her that it is not a place for entertainment. She says "I thought these would brighten your parlor a little ... It's a shame more sun doesn't get in her.” (Ishiguro, 34) Here, Stevens' attitude toward Miss Kenton's romantic endeavor to come close to him is marked by contradiction and inconsistencies. 
In many ways, Stevens appears as emotionally blind to Miss Kenton's feelings. He always tries to stick to his principle of professional dignity that does not allow the development or even the initiation of any romantic relationship. Miss Kenton is aware of his ambivalent feelings toward her. Another incident that shows Stevens indifference to Miss Kenton's romantic attitude toward him takes place when Stevens is reading a book in his pantry and Miss Kenton enters without his permission. Stevens is appalled upon seeing her inside his room. Spontaneously, he goes to hide the book so that she will not know the type of book he is reading. Also, he goes to give some untrue explanation to this action. In fact, Stevens is reading a romance. Out of his embarrassment, Stevens goes to avoid any contact with her by turning his hand away. Moreover, he tries to overcome the tension of the situation by throwing the book into a drawer. To him such an action of reading a romance is personal and can be suppressed. Stevens also goes to justify his act from a professional point of view stating that he is reading it to improve his language. Stevens says "There was a simple reason for my having taken to pursuing such works; it was an extremely efficient way to maintain and develop one's command of the English language .... I consider it my duty to develop as best as I could.” (Ishiguro, 112)

On the other hand, Stevens reveals in his reminiscence, his anguish over the incident of the book showing an emotional engagement that he is not willing to accept. He says that he "find an incidental enjoyment from the book and asks why one should not enjoy in a light-hearted sort of way stories and gentlemen who express their feelings for each other, often the most elegant phrases." (Ishiguro, 112) Commenting on the incident as a whole, Penner remarks "The incident demonstrates the incompatibility of sexuality and Stevens; carefully constructed role as a butler. The important principle that he stresses in connection with the scene in the fact that he was off duty." (Penner 1999, 46) thus, Stevens inability to act on his feelings somewhat blinds his, making him unable to respond adequately to Miss Kenton's feelings.

Having rejected the flowers and denied his interest in reading romantic books, Stevens displays ambivalent feelings toward Miss Kenton. Miss Kenton can anticipate some hope in Stevens' affection toward her. To reach a conclusion about her relationship with him, she starts to ask Stevens some questions about his future plans to see if there is still any hope of their future union. She wants to assure if he thinks of getting married to her or not. Miss Kenton thinks that marriage to him may be an option. She says to him "It occurs to me that you must be a well-contended man. Here, you, after all, at the top of your profession, every aspect of your domain well under control. I really cannot imagine what more you might wish for in life." (Ishiguro, 110)

In his reply to Miss Kenton's question about his future plan, Stevens involves in a long talk about how he is going to devote his life to his career. He replies with absolute coldness. Miss Kenton goes to tell him that she has a marriage proposal from Mr. Benn she wants to leave Darlington Hall for Marriage. In fact, Stevens does not want her to go telling her "It would constitute a professional loss of some magnitude, a loss Darlington Hall would have some difficulty recovering from." (Ishiguro, 99) Here, again Stevens considers Miss Kenton leaving Darlington Hall from a professional point of view. Upon informing him about her acceptance of Mr. Benn's marriage proposal, Miss Kenton wants to know his real feelings toward her. As Iverson puts it "Miss Kenton wants him to speak his mind but he is unable to do so. He does not speak his mind partly because he is bound by his professional duty. Stevens does not feel something even if he does not act on it." (Iversen 2014, 25)

To the news of Miss Kenton's acceptance of Mr. Ben's proposal, Stevens congratulates her without discussing the matter. Of course, he is unable to handle the situation in a way to show any interest on his part toward any possibility of future union. He does not want to satisfy a personal desire on the expense of his professional duty. That is to say, he prevents his professional relationship with her deviating from the professional basis and, therefore, this ruins any possibility of any romantic relationship. Having decided to leave for marriage, Stevens maintains a high level of selfcontrol over his feelings. He shows no interest in asking her to stay. Of course, Miss Kenton feels hurt upon his indifference to the chance she gives him to express his desire to ask her not to leave. Eventually, Stevens confronts her with his observation explaining that he has to take care of the welfare of the house. Both Stevens and Miss Kenton are in the habit of taking cocoa together in his room. Upon her acceptance of the marriage proposal, Stevens stops their daily meeting. In recollecting this scene, Stevens ponders upon it stating "I only speculate over this now because in the light of subsequent events, it could well be argued that in making my decision to end those evening meetings once and for all, I was perhaps not entirely aware of the full implications of what I was doing." (Ishiguro, 117)

Lord Darlington is known for his sympathy toward the Nazi. He has some good connections with some German friends. There are two Jewish maids working among the staff at Darlington Hall. Lord Darlington is influenced by his German friend. As a result, he decides to dismiss the Jewish maids. He asks Stevens to dismiss them. Stevens, though not happy with his master's decision, has to comply with the order and asks the maids to leave. He justifies his obedience in carrying out his employer's command stating "It is that demands to be carried out with dignity." (Ishiguro, 98) On the contrary, Miss Kenton does not approve the dismissal of the maids. She scorns Stevens saying "Why Stevens, why, why, why do you always pretend?" (Ishiguro 102) Stevens tells Miss Kenton that he sees it as irresponsible to question his duties and that it is their duty to follow the orders of their master. However, Miss Kenton is bold enough to speak her mind and shows her feelings remarking "Does it occur to you that to dismiss Ruth and Sarah on these grounds would be simply wrong? I am warning you I will not continue to work in such a house." (Ishiguro, 98) in this regard, Bruce points out "Miss Kenton puts up no opposition and says nothing though, she never appreciate what has been done. She expresses her anguish at having done nothing." (Bruce 2007, 81)

All in all, Stevens-Miss Kenton's relationship is not one based on mutual affection and feelings. Though Stevens has some inherent romantic feeling toward her, such feelings are buried alive in the name of professionalism. He is so busy 
trying to achieve the status of a perfect butler that he tends to be oblivious about his real feeling toward Miss Kenton. Again, the contradictions and inconsistencies that Stevens develops are characteristics of the postmodern man living in a world riddled with fragmentation and anxieties. Such contradictions and inconsistencies are adopted as a means of coming to terms with the ever-changing present world. Really, it is a world where one has to cope with through adopting varying attitudes toward its people. In a word, Stevens is endeavoring to construct a new identity in through process of varying his stances in the new world.

\section{Stevens' New Outlook to his Present Life}

Toward the end of the novel and after his encounter with Miss Kenton Stevens' character and attitude experience drastic changes that expose him as a mere postmodern figure suffering from anxiety. In fact, such anxiety is a direct result of his changing attitudes toward the people around him especially his master Lord Darlington, his father and Miss Kenton. Thus, Stevens appears as suffering from an identity crisis on account of the inconsistencies and contradictions that characterize him throughout the novel. Stevens regrets all his past conducts. He reaches good understanding of the reality of life. As Penner remarks "Stevens has undergone a series of experiences and introspections which brings him at the end to some sort of deepeneb understanding of the social realm that has escaped him. It has become a socializing experience, marked by moments of creative self-reflection which leaves him changed and more fully realized within the suffocating routine which had been his life.” (Penner 1999, 29)

Stevens comes to a point where he starts to regret his past life. He who has been so dutiful and serious minded changes his mind and decides to make the best of what remains of his life. He wants to develop a more positive attitude toward his present life. He is experiencing self-recognition of some kind. He wants to come to terms with what present life may offer considering his past life as a waste life. Now, he sees it as a life of self-abnegation and repression. In a moment of reflection, Stevens reveals "What is the point of worrying too much about what one could or couldn't have done to control the course one's life took? Surely, it is enough that the likes of you and I at least try to make our small contributions count for something true and worthy." (Ishiguro, 164)

Stevens' growing awareness and regret of his past life can be clearly seen in regretting his blind obedience to Lord Darlington. This regret toward his master results in regretting the kind of life he has been living. Eventually, he realizes that his utter dedication to professionalism has been a form of self-denial. Stevens is experiencing a moment of insight which makes him regret his past life with Miss Kenton and his previous denial of any romantic feeling toward her. Lawrence Graver remarks "the pattern of simultaneous admission and denial, revelation and concealment emerge as the defining feature of the butler's personality." (Graver. 1989, 16)

In his relationship with Lord Darlington, Stevens displays inconsistency in the form of his changing attitude between past and present. Early in the novel, Stevens appears very proud of working for Lord Darlington. As Lawrence Graver states "Although Stevens is too honest to provide all the incriminating facts about Lord Darlington, he is still caught up in his own dream of serving a gentleman." (Lawrence 1989, 17) Stevens chooses to deny anything that might deter him from his absolute dedication to Lord Darlington. As a perfect butler he has to "practice some self-control that prevents him from the fulfillment of his duties." (Davis. 1996, 60) In stating his trust and pride in working for Lord Darlington, Stevens says "I trusted in his lordship wisdom. All those years I served him. I trusted that I was doing something worthwhile. I can't even say I made my own mistakes." (Ishiguro, 164) In another occasion, Stevens states his pride in working for Lord Darlington saying "The employer embodies all that I found noble and admirable, I will hereafter devote myself to serving him." (Ishiguro, 136)

On the other hand, Stevens sometimes denies his social background when circumstances demand it. He denies working for Lord Darlington twice. Also, he denies his association with Lord Darlington when asked by Mrs. Makefield. First, he appears reluctant to answer Mrs. Makefield's question saying "It's not customary in England for an employee to discuss his past employers. It's true that he feels ashamed of his previous attachment to Lord Darlington." (Ishiguro, 132) In this regard, Darlympe points out "Stevens' struggle to maintain the philosophy that he has used to excuse his life-long self-deprivation. Stevens holds loyalty in keeping with values of dignity and professional duty. But has repressed the fact that his unquestioning service for Lord Darlington was not intelligently bestowed or dignified at all." (Darlympe 2011, 26)

Thus, Stevens has come to a realization that his past life and his concept of professionalism along with his concept of dignity are not quite enough to justify that kind of life he has lived in the Darlington Hall. Stevens' character has undergone a shift from more submission to professionalism represented in his belief that "If a butler is to be of any worth to anything or anybody in his life, there must surely come a time when he ceases his searching." (Ishiguro, 136) Stevens' new adopted belief of his service to Lord Darlington comes to be "How can one possibly be held to blame in any sense because, say the passage of time has shown Lord Darlington's effort, were misguided, even foolish ... and it is quite illogical that I should feel any regret or shame on any account." (Ishiguro, 136)

On the other hand, Stevens can be seen in a moment of self-recognition upon meeting Miss Kenton after a long period of being away from each other. Miss Kenton tells him that she has tried to get him to respond to her affection. She confesses that she wishes she has got married to him. Stevens, for the first time, reveals his sorrow over ignoring her affection toward him. He must adapt to a new kind of life seeing his previous life as a wasted life. Commenting on what his life has eventually come to stating:

What is point in worrying oneself too much about what one could or couldn't have done to control the course one's life took? Surely, it is enough that the likes of you and I at last try to 
make our small contributions count for something true and worthy. And if some of us are prepared to sacrifice much in life in order to pursue such aspiration, surely that is in itself, whatever the outcome cause for pride and consolation. (Ishiguro, 161)

In another occasion Stevens states:

After all, what can we ever gain in forever looking backward blaming ourselves of our lives have not turned out quite as we might have wished? The hard reality is, surely, that for the likes of you and me, there is little choice other than to leave our fate, ultimately in the hands of those great gentlemen at the hub of this world who employ ourselves. (Ishiguro, 161)

\section{Conclusion}

By and large, Stevens can be seen as an example of a postmodern character who finds himself in a dilemma between the past and the present. He leads a life of distraction as a result of his inability to identify himself with the past nor the present. Really, he is suffering from an identity crisis. He appears as a man without a family or class struggling to form a self for himself. He lives at the margin of society dedicating his life to his master. Stevens realizes that his past life has been a failure after it is too late. Eventually, he realizes that he has been striving to reach the unattainable. Daniela Carpi states:

Stevens is the social subject, divided between tradition and the past codes on one hand, and the rejection of assessed trends and the advocacy of a new autonomy on the other. Living in the margin of class hierarchies, operating as an intermediary between aristocracy and bourgeois. (Carpi 2012, 168)

Thus, the concept of identity Stevens has formed has depended on the function of the memory as memory is the fundamental force behind self-understanding and self-realization. In memories, Stevens finds some energy to keep moving forward.

Ishiguro's The Remains of The Day could skillfully provide an example of a postmodern man who finds in his past life a driving force for constructing a better life in the present to live the remains of his life. Actually, he has lived a life of deprivation of all kinds of private or personal feelings or emotions. A life devoid of any sort of pleasure at the personal level. Therefore, from Stevens' story, one can also learn that the individual's inability to speak his mind freely and suppress his feelings and emotion when it is necessary, opens the door to the possibility of repeating other people's mistakes. In a word, reading The Remains of The Day provides an invitation to everyone to liberate himself from any kind of domination that might result in a life of self-abnegation. It also provides an invitation to liberate ourselves from the social, cultural or ideological barriers that might hinder us from leading a live of our own and not a life for others.

\section{References}

Bruce, Susan. 2007. "Illusions of Absence: Disappearances, Displacement and The Limits of Responsibility in The Winter Tale and The Remain of The Day." http://id.eruditiorg/iderudit.

Carpi, Daniela.2012. "The Crisis of The Social Subject in The Contemporary English Novel" European Journal of English Studies. 1-2.

Dalrymple, James. 2011. "Blindness in The Novels of Kazuo Ishiguro: Dignity or Denial?" Literature (dumas. 009321377).

Davis, Rocio G. 2007. Imaginary Homelands Revisited in The Novels of Kazuo Ishiguro. Universidad de Navarra.

Foniokova, Zuzana. 2006. “The Butler Suspicious Dignity: Unreliable Narration in Kazuo Ishiguro's The Remains of The Day". Brien Studies in English.

Graver, Lawrence. 1989. "What The Butler Saw.” Book Review Desk.

Groes, Sebastian. 2011. "It's Good Manners, Really." Kazuo Ishiguro and The Ethics of Empathy.

Hartwig, Heidi.2013."Sentiment and History in The Remains of The Day": Essay and Studies, 1-2, August.

Ishiguro, Kazuo. 1989. The Remains of The Day. Faber and Faber: London

Iversen, Yvonne. 2014. The Remains of The Day, Tradition and The Individualist Survivor. An MA Thesis. University of Agder.

Johansson, Kenny. 2011. "The Self-contradictory Narrative of Mr. Stevens in Kazuo Ishiguro's The Remains of The Day. ENIO2 Literary Essay. University of Gothenburg.

Lalrinfeli, C. 2012. A Study of Memory and Identity in Selected Works by Kazuo Ishiguro. A PhD Dissertation. PhD Scholar, Mizoram University. Azawl.

McLeod, John Martin. 1995. Rewriting History: Postmodern and Postcolonial Negotiations in The Fiction of J. G. Farrell Timothy Ma, Kazuo Ishiguro's and Salman Rushdie: A PhD Thesis, The University of Leeds. School of English. 
Penner, Tom. 1999. Performing Liminality: Kazuo Ishiguro's The Remains of The Day and Anita Krookner's Look at $M e$ : A Published Master's Degree, University of Manitoba Winnipeg.

Petry, Mike. 1999. Narrative of Memory and Identity: The Novel of Kazuo Ishiguro. Frankfurt. Main: Lang.

Scherzinger, Karen. 2004. The Butler in The Passage: The Liminal Narrative.

Sutcliffe, William. 2000. "History Happens Elsewhere". Independent on Sunday. Sunday Review.

Szederkenyi, Eva Katalin. 2014. Gaps and Silence in Reinterpreting The Past: The Development of Kazuo Ishiguro's Techniques in his Early Novels. A PhD Thesis, Budapest.

Teruko, Takanash. 2012. A Metaphorical World Described by an Unreliable Narrator: Kazuo Ishiguro's The Remains of The Day. Nihan University, Graduates School of Social Cultural Studies.

Thomas, Diane. 2012. Identity, Identification and Narcissistic Phantasy in The Novels of Kazuo Ishiguro. A PhD thesis, University of East London .

Weller, Saranne. 2007. "To Abandon Their Professional Being for The Private One at The Least Provocation: The Problem of Self in Reflective Practice Models of Professional Development." King's Learning Institute. London.

Wong, Cynthia. 2005. Kazuo Ishiguro: Writers and Their Work. Horndon: Northcote.

Yazgi, Cihan. 2013. Hegemony and Value Construction in Kazuo Ishiguro's The Remains of The Day and Never Let Me Go: A Marxist Reading. An MA Thesis. The Graduate School of Social Sciences of Middle East Technical University. 